
Digitized by the Internet Archive in 2012 with funding from

Agriculture and Agri-Food Canada - Agriculture et Agroalimentaire Canada 


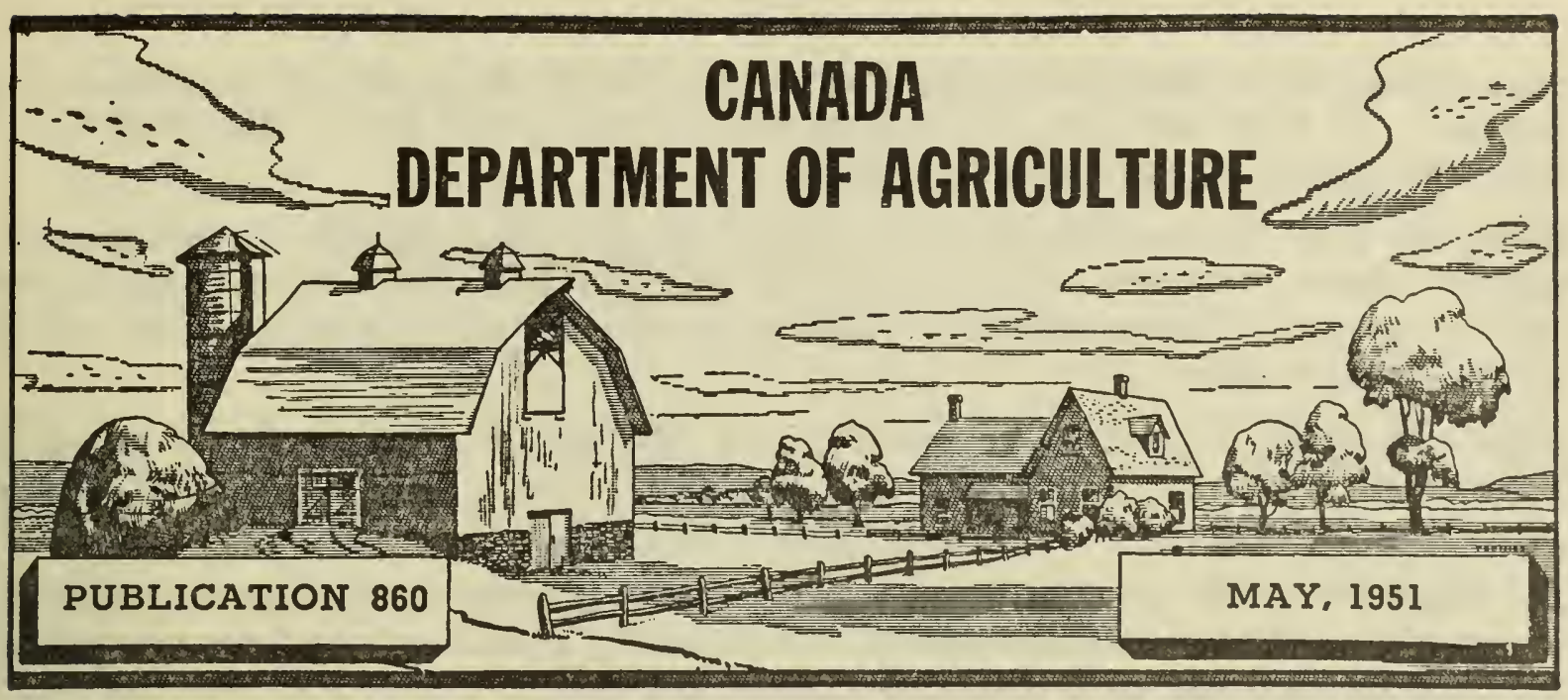

\section{ANNUAL CROPS FOR HAY AND PASTURE}

Successful livestock and dairy farming depends upon good pastures and satisfactory yields of hay and other roughages. Many farms lack adequate pasturage for the livestock they are carrying. Furthermore, the failure or partial failure of the hay crop frequently presents another real problem. Hay and pasture may have been badly injured by winter-killing, drought, floods or other adverse conditions. Often, poor catches on newly seeded fields are not noticed until the following spring when it is too late to reseed to biennial or perennial species. Sometimes legumes and grasses are killed out in low-lying areas or hollows, thus forcing the farmer to fall back on an annual crop.

\section{Annual Forages Recommended}

When a shortage of hay or pasture is threatened it is necessary to resort to the use of annual forages. Generally the same species may be used for hay and for pasture. The chief crops, successful as supplements, are, oats; oats and sudan grass; oats and fall rye; oats and sweet clover; oats and peas; oats, peas and vetch; oats and Italian rye grass; sudan grass; millet; soybeans; soybeans and sudan grass; fall rye; rape; kale; sorghum; wheat; barley and corn.

\section{Rates, Method and Time of Seeding Different Crops}

Oats.-Seeded alone at the rate of two to three bushels per acre oats may be grazed in four to five weeks after seeding or from the time the crop is not more than one foot in height. Oats may be cut for hay when the grain is in the milk stage.

Oats are palatable and nutritious and well relished by livestock. The only disadvantage, particularly in Eastern Canada, is that oats give a poor aftermath following the first cutting or grazing. Where leaf or stem rust is prevalent resistant varieties, recommended for the area, should be used. Where available Roxton oats are recommended for use in Eastern Canada.

Oats and Sudan Grass.-Oats are usually seeded at two bushels and sudan grass at twenty pounds per acre. Such a mixture provides considerably more pasture than oats or sudan grass alone. The oats grow quickly and furnish pasture early. Sudan grass makes its best growth when the soil gets warm and usually after the oats have been grazed or mowed off once. This mixture should be seeded

$\begin{array}{ll}10 \mathrm{M}-15060-5: 51 & \begin{array}{l}\text { Canadian Agriculture Library } \\ \text { Bibliotheque canadienne de l'agriculture } \\ \text { Canada }\end{array} \\ \text { Ottawa K1A OC5 }\end{array}$


about June 1. A similar mixture may be used as a nurse crop in a rotation for pasture. In this case the rate should be reduced to one and a half bushels of oats and fifteen pounds of sudan grass.

Oats and Fall Rye.-This mixture seeded in the spring usually provides more pasture than oats alone. It may be cut once for hay and pastured thereafter until freeze up. The usual rate of seeding is two bushels of oats and one bushel of fall rye per acre.

Oats and Sweet Clover. - The seeding of a mixture of oats and sweet clover is popular in Western Canada and in parts of Ontario. Oats are seeded at two bushels and sweet clover at fifteen pounds per acre.

Oats and Peas.-In the Maritime Provinces and in parts of Quebec and Ontario a mixture of two bushels of oats and one bushel of peas has long been recognized as a soiling crop and as a desirable annual hay crop.

Oats, Peas and Vetch.-Vetches, at the rate of thirty to forty pounds are often added to the mixture of oats and peas mentioned above, especially in the Maritime Provinces. This combination makes excellent hay, but it is not recommended for pasture, because peas and vetches contribute little forage at the time oats are ready for grazing and the additional cost for seed is not warranted.

Oats and Italian Rye Grass.-Oats at two bushels and Italian rye grass at twenty to twenty-five pounds per acre has given very satisfactory pasture at Ottawa. Italian rye grass in this mixture furnishes a very good, green and attractive pasture after the oats are grazed off.

Sudan Grass.-This annual grass is an excellent hay or pasture plant. Seeded at thirty pounds per acre not before May 30, sudan grass gives a very good pasture in about six weeks, or it may be cut for hay when in bloom which is about ten weeks from date of seeding.

Sudan grass will grow on any type of soil adapted for corn. It should be seeded on well prepared, clean land about the same time that corn or soybeans are usually planted. Sudan grass will not thrive on cold, poorly drained or very heavy soil. It is easily damaged by fall frosts.

The best method of seeding is with a grain drill, using the wheat section, but care should be taken not to sow the seed more than one to one and a half inches deep. Sudan grass may be sown broadcast, harrowed and rolled if the land is loose and in good condition, but better results may be obtained by drilling.

Sudan grass is known to contain prussic acid and in the United States, there have been isolated cases of stock poisoning from this crop. There are no authentic reports of any trouble of this kind in Canada. However, it is well to avoid pasturing very young or stunted sudan grass, or crops that have been frozen.

Millet.-A number of varieties of millet have been grown successfully for hay or for pasture. Millet may be seeded later than oats alone or oats in mixtures with other species. Most varieties of millet may be seeded as late as July 15 if moisture conditions are favourable. It is not so well adapted to cool seasons as oats, but under such conditions millet does better than sudan grass. It is particularly useful for hay or soiling crop, and may also be used for pasture. Millet may be sown late in the summer making it possible to utilize land which otherwise would remain relatively cropless.

Millet should be sceded with a drill on good, clean, warm and well prepared land, at twenty to thirty pounds per acre, depending on variety, and cut for hay as soon as the plants are in head. It may be used for pasture when it is ten inches to one foot in height. 
Some of the varieties commonly used are: Japanese, Siberian, Hungarian, Crown, Empire, Hog, Golden and Common.

Soybeans.-Suitable varieties of soybeans seeded in drills may be used for hay. Seeded alone, soybeans are not well adapted for pasture because they give little second growth after the first grazing. They are an annual legume crop, and may be used to supplement straight grass hay as are clover or alfalfa.

Soybeans should be seeded on clean land at two to two and a half bushels per acre about corn planting time and cut for hay with an ordinary hay mower when in bloom, and the pods are forming, but long before the seed is ripe. Soybean hay is handled similarly to alfalfa or red clover hay.

The variety of soybeans is not so important when used for hay or pasture as when grown to maturity for seed. Good results have been obtained with Mandarin, O.A.C. No. 211, Kabott, A.K. and Pagoda varieties when grown for hay, but any late-maturing, leafy, fairly tall variety may be used.

Soybeans and Sudan Grass.-This mixture makes excellent pasture, particularly in Ontario or where these crops grow well when seeded separately. The soybeans are drilled in at one to one and a half bushels with the sudan grass, which is usually seeded broadcast, at fifteen to twenty pounds per acre. Often soybeans are seeded in rows by blocking off every other or every third run of the grain drill. Sudan grass may then be broadcast as late as two to three weeks later and harrowed in with a light drag harrow, even if the soybeans are well up.

Under favourable conditions a seeding of soybeans and sudan grass produces a palatable pasture of almost pure soybeans at the time it is grazed first, and sudan grass yields well during the remaining part of the summer. This mixture is not popular because of the cost of seed and labour in seeding the crop in two operations.

Fall Rye.-This crop is becoming increasingly popular, particularly for very early spring pasture when it may be grazed to give grass pastures a chance to get well established. Seeded as early as August 1 , fall rye may provide late fall pasture. If seeded later than September 1, it should not be grazed until the following spring. Fall rye should be seeded at two bushels per acre on well prepared land in fair state of fertility.

Varieties recommended are:-Horton, Rosen and Crown; Dakold variety is late and prostrate in habit of growth at first, but it may be used to furnish pasture later than the other varieties mentioned.

Rape.-This leafy plant gives a high yield of green herbage, but because of its high moisture content, does not yield as much dry matter as oats or combinations of oats with sudan grass or other species. However, it provides excellent pasture, particularly, late in the fall since it is not readily injured by frost. It has been found very satisfactory for finishing lambs or for "flushing" of ewes for the mating season. It is used extensively as pasture for hogs.

Rape may be seeded alone or with oats, the rape being seeded broadcast or in rows. Seeded alone in rows and cultivated it produces very heavy yields with little waste in pasturing.

The variety commonly used is Dwarf Essex, seeded at four to five pounds per acre, if broadcast, or two to three pounds per acre if in rows twenty-four to thirty inches apart.

Kale.-This crop is frequently used in place of rape for finishing lambs in the fall or for pig pasture. The stems of kale are coarser but more succulent than those of rape. The methods and rates of seeding kale are similar to those for rape. Seeded when the ground is suitable for sowing grain in the spring until the latter part of July, kale or rape will be ready for pasturing in six to eight weeks. 
There are many varieties of kale to choose from, among them Green Stem Marrow, Purple Stem Marrow, Thousand Headed and Curled Sheep kale.

Sorghum.-This crop will not yicld as much as corn, but it can be sown later and as a soiling crop it has a distinct advantage, since upon cutting it quickly recovers and make new growth. It may be made inito hay, ensiled or cut with a binder and cured in the shock.

As in the case of sudan grass, some varieties of sorghum contain appreciable amount of prussic acid. While there is no danger of feeding dry hay or ensilage, this crop should be handled carefully when used as pasture.

Low acid varicties are recommended such as Rancher and Dakota Amber I ow Acid. Black Amber variety is also good. It may not produce as much as others but it is early and is fairly low in prussic acid content. Sorghum may be seeded in rows, at 10 to 12 pounds or drilled broadcast at 30 pounds per acre.

Other Species for Annual Forage.-Wheat or barley are sometimes used for hay or pasture purposes. Annual sweet clover, chiefly Hubam and Melana may be seeded early for hay without a nurse crop at twenty to twenty-five pounds per acre. Corn when drilled thickly, will produce considerable green feed for soiling purposes or may be made into ensilage.

In areas where corn grows well, additional acreage may be seeded to corn in order to provide green feed from about the end of July, and to ensure from four to six weeks supply of ensilage for feeding during the following summer.

While the above annual crops may be used to advantage to supplement biennial and perennial pastures, the aftermath from meadows will continue to provide most additional pasture during late summer and early fall periods, when permanent pastures are relatively unproductive.

\author{
Revised by F. S. Nowosad, \\ Experimental Farms Service, \\ Canada Department of Agriculture, \\ OTTAWA.
}

